\title{
Balkanologie
}

Balkanologie Revue d'études pluridisciplinaires

Vol. $16 n^{\circ} 1 \mid 2021$

Au-delà de la "route des Balkans ": mondes sociaux des circulations

\section{From Labour Migrants to a Diaspora Community? The Case of Ukrainian Migrants in Greece}

Des travailleurs migrants à une communauté diasporique? Le cas des migrants ukrainiens en Grèce

\section{Kira Kaurinkoski}

\section{OpenEdition}

\section{Journals}

Electronic version

URL: https://journals.openedition.org/balkanologie/2750

DOI: 10.4000/balkanologie. 2750

ISSN: 1965-0582

\section{Publisher}

Association française d'études sur les Balkans (Afebalk)

\section{Electronic reference}

Kira Kaurinkoski, "From Labour Migrants to a Diaspora Community? The Case of Ukrainian Migrants in Greece", Balkanologie [Online], Vol. 16 n 1 | 2021, Online since 01 June 2021, connection on 03 October 2021. URL: http://journals.openedition.org/balkanologie/2750 ; DOI: https://doi.org/10.4000/ balkanologie. 2750

\section{This text was automatically generated on 3 October 2021.}

(c) Tous droits réservés 


\title{
From Labour Migrants to a Diaspora Community? The Case of Ukrainian Migrants in Greece
}

Des travailleurs migrants à une communauté diasporique? Le cas des migrants ukrainiens en Grèce

\author{
Kira Kaurinkoski
}

\section{AUTHOR'S NOTE}

An earlier version of this paper was presented at the Second International Conference on Post-Soviet Diaspora(s) in Western Europe 1991/2019, in Lisbon, Portugal, 15-17 December 2019.

I wish to thank Anastasia Christou, Domna Michail, Katerina Seraïdari, and the anonymous evaluator at Balkanologie for their critical comments and helpful Edwards for his expert advice on migrant population statistics in Greece, and to Jennifer Cash for the thoughtful revision of English.

\section{Introduction}

1 Migration from Ukraine to Greece and to other Mediterranean countries can be characterised as global networked transnational migration. ${ }^{1}$ Transnational migration is characterised by temporary and circular mobility, implying regular contact with the country of origin and transnational migrant networks. ${ }^{2}$ These networks can be defined as a set of international ties that connect migrants, former migrants, and non-migrants in the country of origin and destination based on kinship, friendship, and locality. ${ }^{3}$ Their utility has been recognised in the search for employment and housing, access to goods and services, and also as a source of psychological support and information. ${ }^{4}$ In 
parallel, migrant networks are based on specific values and norms of confidence, obligation, and reciprocity that bind members of a given group. ${ }^{5}$ While networks give privileged access to resources, they also tend to limit migrants' personal liberty and control their behaviour and possibilities to take action. ${ }^{6}$ Moreover, recruitment through such informal networks tends to canalise migrants into jobs with low salaries and prestige. ${ }^{7}$ The forms of solidarity observed in this context are not necessarily durable and reproductible; they are discursively constructed "networks of exchange" and "performances of community" which are fluid, emerge in the moments of enactment and interaction, and are sometimes virtual. ${ }^{8}$

2 People identified as "migrants" maintain enduring ties to their native homeland while being incorporated into their host societies. ${ }^{9}$ Seen from a transnational perspective, therefore, migrants are not fully uprooted. Instead, they move back and forth across international borders and between different cultures and social systems. ${ }^{10}$

3 In their host societies, migrants and their identities are subject to a hierarchy which varies according to the status of the sending country in the "global hierarchy of nations." ${ }^{11}$ The sending country's geopolitical and economic position not only affects the political and legal reception of its migrants abroad, but also influences their position in the labour market, as well as their cultural and social acceptability. ${ }^{12}$ In some cases, it seems that ascribed social characteristics such as colour, gender, national origin, and ethnicity, more than personal achievements and skills, determine whether global mobility becomes truly liberating or simply perpetuates and exacerbates preexisting systems of subordination by reproducing them in multiple localities. ${ }^{13}$ Ultimately, it is a combination of external host society reception and the migrants' human and social capital that determines their socio-economic success and integration. ${ }^{14}$ With "social capital," I refer to the nature and extension of social contacts that one can mobilise, and to a set of informal values and norms that are shared by the members of a given group and allow them to cooperate with each other. ${ }^{15}$

Identity in the context of migration has been studied through the situational approach introduced by Barth, ${ }^{16}$ and the instrumental approach that focuses on ethnicity as a political strategy used for pragmatic purposes. ${ }^{17}$ In the end, people have always been more mobile and identities less fixed than the static and typologising approaches of classical anthropology would suggest. ${ }^{18}$ When groups migrate, they recompose in new settings, reconstructing their histories and their ethnic concepts. ${ }^{19}$

5 This paper discusses the characteristics of Ukrainian migration to Greece. It presents the pre-migratory context, motivations, and expectations. It then analyses the migrants' actual experiences in Greek society and beyond. The paper concludes with a discussion on social organisation, identity, and belonging in a globalised world. Where do the migrants see their future and where do they feel that they belong?

6 Methodologically, this paper is based on semi-structured interviews conducted by the author in greater Athens, as well as secondary sources. The interviews were conducted between 2001 and 2006, and between 2012 and 2015. ${ }^{20}$ My prior doctoral research in Ukraine in the 1990s was valuable in approaching the Ukrainian immigrant community in Greece. ${ }^{21}$ I thus had gained insight into the migrants' culture and country of origin, and an understanding of the social world and the conditions they had left behind, as well as the imaginaries related to Westward migration. 


\section{Ukrainian migrations to Greece}

7 Post-independence migration from Ukraine is considered as part of a "fourth wave" of Ukrainian emigration since the late nineteenth century. ${ }^{22}$ This wave has been explained by the economic difficulties that Ukraine has faced since independence: a high unemployment rate, the lack or low level of social services (particularly in the fields of education and health), and a feeling of insecurity. Social inequality exacerbated by lack of access to higher education after the break-up of the Soviet Union also triggered migration, among younger people for their own futures, but especially to secure "good" education for their children. ${ }^{23}$

Between 1991-2021, Ukraine's population has decreased from 52 to 41.9 million (excluding the autonomous republic of Crimea and Sevastopol which were annexed illegally by Russia in 2014). ${ }^{24}$ This decrease reflects natural decline as well as migratory out-flows. In 2007, Ukraine logged the third highest number of emigrants in the world (Russia and Mexico occupied the first two places, while India and China were fourth and fifth). ${ }^{25}$ Russia has been the main country of destination. In parallel, another 5-7 million Ukrainians have been working abroad, full-time or seasonally, and often irregularly, mainly in the fields of agriculture, construction, services, and care. ${ }^{26}$ This temporary migration has been directed principally towards neighbouring countries: Russia, Poland, the Czech Republic, as well as Turkey and the Mediterranean countries, namely Portugal, Spain, Italy, Greece, and Cyprus. ${ }^{27}$ The years 1994-1998 were an important period of Ukrainian immigration to the European Union (EU). By 2000, Ukrainians already constituted a visible group, particularly in Greece, Italy, and Portugal. ${ }^{28}$

9 After 2008, a slight decrease in temporary Ukrainian migration has been observed. This decrease has been explained by the global economic crisis and the reduced demand for Ukrainian workers in the EU and Russia. A shift in destinations has also been observed. In the years 2005-2008, Russia, Italy, and the Czech Republic were the top destinations of Ukrainian migrants, whereas in 2010-2012, the top destinations were Russia and Poland. In parallel, migration strategies of Ukrainian migrants have changed: earlier, migration was mainly inspired by experiences of migration gained over many years and by extensive migration networks in the destination country, whereas more recently preference has been given to temporary and circular migration which makes it easier to maintain close relations to the homeland..$^{29}$ Repeated migration and involvement of more than one household member in recent labour movements also characterise Ukrainian temporary migration patterns..$^{30}$ The annexation of Crimea and the war in Eastern Ukraine produced an increase in internal migration.

In the end, economic migration is also political. In practice, migration categories are often blurred, and reasons for migration mixed. With respect to types of migration labour, forced, and other -sociologists have demonstrated frequently that the migrants themselves have rather mixed motivations. Rigid ascriptions, such as labour migration, are politically constructed and unsuitable for capturing the complex realities of human lives. They also fail to account for changes in an individual's situation. ${ }^{31}$ In some cases, migration is an exit-strategy and an expression of discontent. It can also be a protest against certain economic or political conditions, and a kind of social movement for participation and social justice. Migration should thus be understood within the 
context of social inequality, bearing in mind the stratification of society and the political meanings of migration or sedentariness. ${ }^{32}$

11 Gender affects every aspect of the migratory experience: its causes, patterns, processes, and impacts, including the subjective personal experience of migrants. ${ }^{33}$ Usually, there is a link between the regions of origin, gender, and destination. In terms of gender, in Italy, Greece, ${ }^{34}$ and Cyprus, Ukrainian migration is largely female. Meanwhile, Ukrainian migration to Russia, Poland, and Germany is largely male. Migration to Portugal and Spain was initially male-dominated but has shifted to being genderbalanced in the case of Portugal, and female-dominated in the case of Spain. This differentiation according to gender is largely explained by the possibilities of finding employment in the local labour market in the countries of destination. ${ }^{35}$ Marital status also matters, as it influences the nature of migration and the orientation toward the native homeland and the receiving society. ${ }^{36}$

Greece was until the late 1980s, largely known as an exporter of refugees and migrants.

${ }^{37}$ The picture changed significantly in the 1990s, and in 2001, foreign citizens accounted for approximately $10 \%$ of the population..$^{38}$ The majority of migrants came from the neighbouring Balkan and other Central and Eastern European countries. Albania was the main source country of migrants, followed by Bulgaria, Romania, Georgia, Russia, Ukraine, Armenia, Moldova, and Poland. ${ }^{39}$ Towards 2005, Greece also became a target and transit country for migrants from North Africa, Middle East, and Asia, particularly from Afghanistan, Iraq, and Pakistan. ${ }^{40}$

After the 2008 crisis, Greece lost its attraction as a destination country among Central European migrants. The crisis particularly hit the construction sector where many immigrant men were employed, but also the tourism and catering sectors. Female migrants who worked as cleaners were also affected since many families reduced their household expenses. Additionally, many migrants who lost their jobs also lost their legal residence status since they were not able to renew their work permits. ${ }^{41}$ In total, around half a million Greek residents, amounting to roughly $7 \%$ of the active population, left Greece over the years 2010-2015 in search of employment, better pay, and better social and economic prospects. Over the same period, the unemployment rate reached $25 \%$ in Greece while the economy shrank by a quarter..$^{42}$ This said, over the past ten years, the number of foreign citizens in Greece has decreased to approximately $8 \%$, most of whom come from non-EU countries ( $83 \%$ in 2017) (table 1 ). This is a fact that distinguishes Greece from many other EU-28 countries. ${ }^{43}$

Table 1. Number of foreign citizens in Greece according to the 2011 population census. Main nationalities.

\begin{tabular}{|l|l|l|}
\hline Country & Number & Percentage of Greek population \\
\hline Albania & 480,824 & 4,45 \\
\hline Bulgaria & 75,915 & 0,70 \\
\hline Romania & 46,523 & 0,43 \\
\hline Pakistan & 34,177 & 0,31 \\
\hline
\end{tabular}




\begin{tabular}{|l|l|l|}
\hline Georgia & 27,400 & 0,25 \\
\hline Ukraine & 17,006 & 0,16 \\
\hline USA & 15,386 & 0,14 \\
\hline Cyprus & 14,446 & 0,13 \\
\hline Poland & 14,145 & 0,13 \\
\hline Russian Federation & 13,807 & 0,12 \\
\hline
\end{tabular}

Source: Greek Statistical Service

Migrants who have arrived in Greece in search of work, particularly since 1990, have pluralised the cultural and ethnic composition of the country, thus altering the illusion of homogeneity on which the modern nation, as imagined community, was founded. Greece, however, has done little for the civic incorporation of migrants of non-Greek origin whose naturalisation rates remain low. ${ }^{44}$ Greek citizenship has mainly been given to those who can prove to be ethnic Greeks. ${ }^{45}$ In the case of persons of non-Greek origin, Greek citizenship has been granted principally to children of migrants, born and educated in Greece. ${ }^{46}$ Marriage to a Greek citizen is another way of securing citizenship.

Based on the classification proposed by James T. Fawcett, Marina Nikolova distinguishes between four distinct periods of Ukrainian migration to Greece, a) according to the migration policy in place in the country of departure and arrival; b) family and social networks; c) and the image portrayed by mass culture and other available information ${ }^{47}$ During the first period, before 1991, the migrants were mainly Greek political refugees and their offspring who chose to return to their homeland, and spouses of Greek students who had studied in Ukraine. During the second period, between 1991 and 1998, the great majority of Ukrainian migrants arrived in Greece with a tourist visa, which they overstayed contributing thus to the large stock of irregular migrants. ${ }^{48}$ The third period, between 1998 and 2007, marked a turning point, namely with the implementation of the first legalisation programmes for third country (i.e. non-EU) migrants in Greece. During this period, numerous Ukrainian migrants in Greece attempted to legalise their situation. Additionally, Ukraine was one of the major countries of origin for trafficked girls and women in Greece ${ }^{49}$ Trafficking of women from Ukraine for sexual exploitation decreased between 2003 and 2007 and is not currently a cause for concern. ${ }^{50}$ The fourth period started in 2008 and is characterised by the end of the legalisation programmes, and the challenges that stemmed from the economic crisis in Greece, particularly tangible between 2010 and 2018. Since 2008, Greece no longer attracts significant numbers of new labour migrants from Ukraine. The main reasons are improved living conditions in Ukraine; diminished employment opportunities in Greece; and more reliable information in Ukraine about the position of migrants, work opportunities, and way of life in Greece. These developments, however, do not exclude circular migration and other forms of temporary mobility, while an increase in migration for family reunification has been registered (tables $2 \& 3$ ). ${ }^{51}$ 
Table 2. Number of Ukrainians in Greece according to the 1991, 2001 and 2011 censuses, 1997 legalisation programme, and valid resident permit data as of 15.01.2006, and 27.05.2014

\begin{tabular}{|l|l|l|l|l|l|l|}
\hline Country & 1991 & 1997 & 2001 & 2006 & 2011 & 2014 \\
\hline Ukraine & 61 & 9,821 & 13,616 & 20,283 & 17,006 & 17,298 \\
\hline
\end{tabular}

Sources: BaLdWIN-EDWARdS Martin 2008: 2; Ministry of Public Order, Greek Statistical Service; Ministry of the Interior, Greece.

Table 3. Reasons for Ukrainian migration to Greece according to valid resident permit data as of 27.05.2014

\begin{tabular}{|l|l|l|l|l|l|}
\hline Country & Work & Other & Family reunification & Studies & Total \\
\hline Ukraine & 2,483 & 5,222 & 9,348 & 245 & 17,298 \\
\hline
\end{tabular}

Source: Ministry of the Interior, Greece. citizens in Greece have completed post-secondary education and over 35\% have completed secondary or pre-secondary vocational training. ${ }^{56}$

\section{The pre-migratory context and motivations}

18 Perestroika and the dissolution of the Soviet Union contributed to the constitution of new dispositions and competences as far as mobility is concerned. The opening of borders, the legalisation of commercial activities, the devaluation of the national currency, and the closure of factories led to massive unemployment, and pushed large numbers of Ukrainians on the road. Others continued to do their work but could no longer live on their salaries. Shopping trips to neighbouring countries (tcholnoki) became commonplace. The social acceptance of independent female migration from industrialised European post-Soviet republics, such as Ukraine, in the former Soviet Union and in the host countries, facilitated the departure of women. ${ }^{57}$

The decision to migrate to Greece, as well as to other Mediterranean countries, was primarily a response to the difficult economic situation in Ukraine and reflected the desire to help family members who had stayed behind.

I will present the case of Irina, a technician, with a diploma from the Kiev Polytechnic Institute in Rivno. In the mid-1990s, the factory where Irina was working closed. 
Everybody lost work. Her daughter was still in school and had to study. To cope with the situation, Irina started selling clothes at the local market in Rivno together with her husband. Later she expanded her activities. During the last years before her arrival in Greece she travelled to Moscow, Poland, and Lithuania to buy products that she resold at the local market in Rivno or at the Polish border, 200 kilometres from her hometown, where she had rented an apartment. In 1998, she came to Greece with two other women. One of them was in the fur trade and already had experience in Greece. Irina's husband and daughter stayed in Ukraine. ${ }^{58}$

In some cases, in the case of women in particular, the decision to leave was a means to escape conjugal problems at home (alcoholism, verbal and physical violence), and a way to acquire personal independence; in other words, as an emancipatory project..$^{59} \mathrm{In}$ some cases, mobility and circulation stemmed from previous experiences of mobility. Some had acquaintances working in Greece. Others had debts to pay or needed to pay for their children's university studies. In the 1990s, seen from Ukraine, and considering the restrictive policies of Western European countries on migration, ${ }^{60}$ Greece very much resembled an Eldorado. ${ }^{61}$ This said, the majority among ethnic Ukrainian migrants interviewed did not come to Greece to restart their life there, but as guest workers and temporary visitors, who hoped to return eventually to their homeland. Few had solid knowledge of contemporary Greek language, society, or institutions. ${ }^{62}$

\section{Situation faced upon arrival in Greece: a story of deskilling and exclusion}

Upon their arrival in Greece, unaccompanied Ukrainian women usually started out as live-in domestic workers, cleaning and looking after elderly people or children. ${ }^{63}$ As a rule, domestic care workers in Greece are females from the lowest echelons of society and belong to a "migrant precariat." ${ }^{64}$ Even when their work is decently paid, the work remains culturally undervalued. Others found work in bars, restaurants, or agriculture. Men were typically employed in the construction sector. ${ }^{65}$ This kind of male and female work was often undeclared; salaries were low and the employer seldom if ever paid social security stamps (fig. 1$)^{66}$

Figure 1. Ukrainian migration in Greece by employment sector in 2001

\begin{tabular}{|l|c|}
\hline Administration and direction in public and private sectors & $0,01 \%$ \\
\hline Scientific and artistic work, and similar professions & $0,02 \%$ \\
\hline Technical work, technicians and assistants & $0,01 \%$ \\
\hline Office work & $0,01 \%$ \\
\hline Services and sales professions & $17,5 \%$ \\
\hline Agriculture, cattle-breeding and forestry & $3,2 \%$ \\
\hline Craftsmen, drivers, non-qualified workers, and workers in small businesses & $68,3 \%$ \\
\hline
\end{tabular}




\begin{tabular}{|l|c|}
\hline Declared their profession unclearly & $0,01 \%$ \\
\hline Did not declare their profession & $0,03 \%$ \\
\hline Total & $100 \%$ \\
\hline
\end{tabular}

Sources: Population census 2001, Hellenic Statistical Authority; published in kaURINкоSкı Kira, 2018, op. cit.

When Irina travelled to Greece in 1998, the "chaperone" who already had experience in Greece got off the bus in Northern Greece, leaving Irina and the other woman to continue on to Athens. There they were met by another compatriot who hosted them for one night. They were five persons in one small room. The day after, Irina went to an agency, near Omonia Square, in search of work. She was ready to take any work available and to leave the little room where she had spent her first night. She found a job right away, and left for Ioannina, in North-Western Greece, to take care of an elderly couple. It was not a happy experience. Three months later, Irina returned to Athens where she found another job as a live-in domestic worker. Later, she rented her own apartment and took up cleaning work in private houses. Seven years after her arrival in Greece, she continued to do the same work: she worked six days a week in six different families. At that time, she had a residence permit that she renewed annually. ${ }^{67}$

Generally, over the years, the proportion of Ukrainian migrants working in the domestic sector has diminished, while that working in the hotel and catering industry has risen slightly. Unemployment is at a lower level than in the Greek labour force and among Greece's wider foreign population (fig. 2). ${ }^{68}$

Figure 2. Ukrainian migration in Greece by employment sector in 2011

\begin{tabular}{|l|l|}
\hline Manufacturing & $7 \%$ \\
\hline Constructions & $6 \%$ \\
\hline Wholesale and retail trade, repair of motor vehicles and motorcycles & $9 \%$ \\
\hline Accommodation activities and catering services & $18 \%$ \\
\hline Administrative and support service activities & $9 \%$ \\
\hline Domestic activities & $32 \%$ \\
\hline Other & $19 \%$ \\
\hline Total & $100 \%$ \\
\hline
\end{tabular}

Sources: Population census 2011, Hellenic Statistical Authority; published in NIKolova Marina, MAROufoF Michaela, 2016, op. cit.

25 In parallel, at least part of the migrants have adapted to their new environment, acquired better knowledge of the Greek language, established functioning working relations with their employers, and built up their social capital. ${ }^{69}$ To improve life and 
working conditions, initiative and agency are crucial. Yet not everyone has the required energy and courage, and not everyone is able or willing to adapt to new ways of life, cultural codes, and values. life situation. They knew why they had undertaken the journey: in most cases, to send cash home. After this initial goal was achieved, for many migrants who decided to stay on, things became more complicated. Several interviewees underlined the importance of finding pleasure in life and being surrounded by good people. Svetlana, born into a military family in Soviet Ukraine, who arrived in Greece in 1999, said the following:

I used to have middle class values. Now I have understood how important it is to enjoy life, to live today. Now what counts for me is to be in good health and to have good people around me. However, we do miss the cultural life we used to have. There [in Ukraine] we used to go to the theatre, to museums. I always dressed well. [...] Here my life is completely different. I am satisfied with what I have. I do not live in a basement. The most difficult is to do live-in domestic work. Of course, if I started to think of who I am and what I am, it would be extremely difficult. ${ }^{70}$ sumarised largely as a story of deskilling and social exclusion. Ukrainian female migrants interviewed took pride in the fact that while working in Greece they had given an education to their children and had managed to provide for their families. Others emphasised their level of education which in the Soviet Union was a value as such. Some others have engaged voluntarily in the work of the Ukrainian migrant community through cultural associations, parish work, or as teachers in Ukrainian Saturday schools. By this kind of agency, ethnic Ukrainian migrants seek self-fulfilment while using their know-how and putting it at the service of the migrant community. ${ }^{73}$

\section{Migrants from Ukraine and the Greek society}

No matter what their exact situation in Greece, those identified as ethnic Ukrainians are "ethnic others" (Gk. allogeneis) - that is, strangers and foreigners. As such, in comparison with some other migrant groups (in particular the Albanians in the years 1990-2000, but also other Muslim migrant groups), ${ }^{74}$ ethnic Ukrainians have been rather well perceived in Greek society. The widespread idea, dominant in the 1990s and 2000s, of ethnic Ukrainian female migrants as servants and prostitutes who threatened the stability of Greek marriages - has been nuanced. Individually, they are also 
perceived as good workers and calm persons. Nevertheless, the fact that many of those who previously perceived themselves as Soviet people have rediscovered their Ukrainian national identity in Greece can also be considered a consequence of the socio-economic exclusion that they have suffered in the host country. ${ }^{75}$ Collectively, ethnic self-segregation characterises the situation of ethnic Ukrainian migrants in Greek society. ${ }^{76}$

31 As far as integration in the host society is concerned, marrying a native Greek can be considered as a step forward, or up, on the social ladder. ${ }^{77}$ Marriage also gives privileged access to Greek citizenship, which in turn opens new possibilities as far as career prospects are concerned, at least theoretically. The acquisition of an EU passport with related rights also provides security. This said, several unaccompanied interviewees with children in Ukraine deliberately underlined that they preferred to preserve their inner peace and did not want potential problems that might stem from a (second) marriage in Greece. Indeed, women who married in Greece have experienced problems securing the reunification of children they had left in Ukraine,$^{78}$ and there are cases in which Greek husbands asked their Ukrainian wives to "forget" their children in Ukraine. ${ }^{79}$ In parallel, part of the ethnic Ukrainian migrants in Greece are still oriented towards Ukraine.

Several ethnic Ukrainian female migrants who were interviewed emphasised that they deliberately had chosen to support their children's education and studies in Ukraine. They did not want their daughters to repeat their experience, to live their life. The loss of face and respect were the most humiliating aspects of the migration experience, said one of them referring to the stigmatisation of ethnic Ukrainian female migrants as sex workers ${ }^{80}$ However, the cost of the migration process has been hard also on the family members who stayed behind. Research conducted in Ukraine and among ethnic Ukrainian migrants in Italy shows that the relative economic well-being of children whose mothers work in Western countries does not compensate for the lack of their mothers' daily care. Children without mothers, and in some cases, without mothers and fathers, are deprived of family socialisation and education, emotional and spiritual support, and often become victims of various social problems. ${ }^{81}$ There is also evidence that children and husbands who have stayed behind develop a materialistic mentality and start perceiving their mothers and spouses simply as sources of financial rewards. ${ }^{82}$ Irina, who arrived in Greece in 1998, while her husband and school-aged daughter stayed in Ukraine, said that in the early years, she sent money home every week. Then one day, her husband started to ask for more money. After this, she stopped sending money, and instead started sending presents, but only for her daughter. In parallel, she opened a bank account in Greece, where she deposited the remainder of her salary. Later, when her daughter enrolled in the university in Kiev, Irina supported her studies by sending 150 USD each month. In 2004, her daughter married. The marriage was celebrated at the Ukrainian Greek Catholic church in Athens. At the time of the interview, the young couple lived in Denmark, and was financially independent. The son-in-law worked in IT and had a good salary. Formally, Irina was still married to her husband but no longer had any contact with him. She praised some of his qualities but was nevertheless critical of the fact that he was not able to provide for his family financially. ${ }^{83}$

While choosing to live the migration experience to improve the economic well-being of their families, many ethnic Ukrainian female migrants have become "servants of 
globalisation," according to the expression coined by Rhacel Parreñas, in her groundbreaking study on migrant Filipina domestic workers who leave their own families behind to do caretaking work on the global economy - at great cost to the relations within their own families. ${ }^{84}$ As in the case of Ukrainian migrants discussed in this paper, the experiences of Filipina migrants studied by Parreñas are also shown to entail a feeling of exclusion from their host society, a downward mobility from their professional jobs in the country of departure, and an encounter with both solidarity and competition from other migrant workers in their communities. ${ }^{85}$

\section{Social organisation and community formation} $1998 ;{ }^{86}$ in 2003, after the death of its founding president, the association split into three: Association of the Ukrainian Diaspora in Greece "Ukrainsko-Grecka Dumka" (Ukrainian-Hellenic Thought), Ukrainian Cultural-Educational Center "Berehynia" (Beregynia), ${ }^{87}$ and Association of Ukrainians in Greece "Ukrainskii Žuravlinii Krai" (Ukrainian Land of Storks). The goal of Ukrainsko-Grecka Dumka is to save Ukrainian identity, language, customs, and traditions, and inform the Greek society about the Ukrainian ancient and modern history and the uniqueness of Ukrainian culture. It takes a position on Ukrainian domestic and foreign policy issues. The association has a Ukrainian Saturday School and five local branches in continental and insular Greece. It is a member of the older Ukrainian diaspora organisations, such as the Ukrainian World Congress (founded in 1967) and the European Congress of Ukrainians (founded in 1949). In 2008, it hosted a Ukrainian diaspora forum in Greece. Berehynia works in close association with the Ukrainian Greek Catholic church, and also has a Saturday school for children. Ukrainskii Žuravlinii Krai has practically ceased to exist, but its choir is still functioning. In 2013, another association, Ukrainci Grecii (Ukrainians of Greece) came into being. In 2020, six Ukrainian cultural associations were registered in Athens. The other two are Support and Development Center of the Ukrainian Cultural Heritage "Trembita" which also operates a Saturday School; and the NGO "Borysthenes, GreeceUkraine Business Hub".

A Ukrainian school (currently, International Ukrainian School) composed of ten classes and acting under the Ministry of Education and Science of Ukraine was opened in Athens in 1999. The three Ukrainian Saturday Schools cooperate with this school. However, most children of Ukrainian migrants in Greece attend Greek public or private schools.$^{88}$ A cultural centre was opened in 2008 as part of the Ukrainian Embassy in Athens where it is located.

In terms of religion, the great majority of ethnic Ukrainians in Greece are Ukrainian Greek Catholics. ${ }^{89}$ On a regular Sunday, 300-400 persons attend mass at the Ukrainian Greek Catholic church, located in the basement of a Greek Orthodox church, in Acharnon Street, in central Athens. After the service, there is a long line of persons 
who wish to speak with the priest. The church is a place where migrants come to meet their countrymen, speak Ukrainian, seek consolation, inquire about available work, etc. In addition to its religious and social role, the Ukrainian Greek Catholic church plays an important role in the consolidation of Ukrainian ethnic, cultural, linguistic, and political identity. ${ }^{90}$ It is the cornerstone of the Ukrainian community in Athens. ${ }^{91}$

Other Ukrainian migrants are Christian Orthodox and attend related services. At the Greek Orthodox church dedicated to Saint Panteleimon, in central Athens, a Ukrainian priest celebrates the service in Ukrainian. Others attend the Russian Orthodox church in Filellinon Street, where the service is held in Church Slavonic and Greek. ${ }^{92}$ Others have no contact with religion or religious institutions.

In connection with the Ukrainian crisis of 2013-2014, the above-mentioned Ukrainian cultural associations organised demonstrations in support of the pro-European forces in Ukraine. In cooperation with the Ukrainian Embassy, they also organised art exhibitions and concerts addressing the war in Eastern Ukraine. Some Ukrainian female migrants in Greece even enrolled as volunteers on the frontline in Eastern Ukraine, while others took care of wounded Ukrainian soldiers who were treated - as a courtesy of state - in Greece. ${ }^{93}$

41 For some migrants, it is sufficient to adjust to the demands of the moment, acquire the necessary skills to deal with practical issues in the new host society, and reconstruct their identities with the view of a "new life" in Greece.

\section{Uncertainty, humility, and visions for the future}

Research suggests that most Ukrainian migrants in Southern Europe do not plan to stay in their host country, but wish to return to Ukraine. ${ }^{94}$ At the same time, Ukrainian labour migration in Southern Europe shows signs of permanence..$^{95}$ This confirms the old aphorism according to which "there is nothing more permanent than a temporary migrant. ${ }^{" 96}$ Regarding Ukrainian migrants in Greece, Rovenchak and Volodko speak of a "myth of return" that persists even after ten to fifteen years in the new host country, and not only among solitary migrants. ${ }^{97}$

In fact, return migration from Greece to Ukraine did start in 2001, when Ukraine showed some signs of stabilisation. ${ }^{98}$ After 2009, return migration from Greece to Ukraine intensified, as Greece's own economy faltered. Migrants who arrived in Greece after 2000 and had lost their work were among the first to leave the country. After 2010, when the economic crisis in Greece became particularly tangible, the departure of families and older female migrants was also observed - for various economic, emotional, and family reasons. Statistically, however, Ukrainian return migration is invisible: as most migrants return to Ukraine voluntarily using their own resources, their departure is not recorded by the Greek state, and since the majority of those who leave probably also hold a residence permit in Greece, ${ }^{99}$ they may continue to move freely between the two countries.

The decision to go back "home" after a long absence is not easy. When the money saved in Greece ends, migrants tend to return or re-migrate elsewhere, as the economic environment in Ukraine, and the lack of re-integration programmes for returning migrants, makes finding a job or starting a small business difficult. ${ }^{100}$ Moreover, during the migration process, the migrants have changed but so has the native homeland, and 
those who stayed behind. Non-migrants often say that the migrants are neither from here nor from there. In other words, they have dissimilated from the mainstream population of the country of departure, and yet, do not form part of the mainstream population in the new host country. A similar observation is made by Domna Michail in relation to the Albanian immigrants in Greece, who are perceived as "Grecos" in Albania, but as "Alvanoi" in Greece. ${ }^{101}$ In the end, both migrants and natives who have stayed in the old home country are subject to change. Flows of ideas, media, commodities, and tourism introduce heterogeneity in both countries. ${ }^{102}$ These are the "social remittances" that accompany the movement of people. ${ }^{103}$

Research on return migration puts emphasis on the necessity of a good preparation and realistic expectations, as well as the capacity to adapt to new conditions as preconditions of successful return. ${ }^{104} \mathrm{~A}$ common practice among Ukrainian migrants in Greece is to enrol their children in the Saturday schools of the Ukrainian community, for them to learn the basics of Ukrainian language, history, and geography with the view of an eventual return to Ukraine. ${ }^{105}$

It can be expected that unaccompanied elderly female migrants who are no longer working in Greece will return eventually to Ukraine. However, families are likely to stay in Greece, if they have work allowing them to sustain themselves. Migrants with adolescent or adult children often say that their future depends on their children. "Where their children will be that is where they see their future." ${ }^{106}$ The case of young single women is different. If they cannot find external work in Greece, they tend to return to Ukraine, and in some cases, re-migrate to neighbouring countries, (e.g. Russia or Poland), where they are likely to find work which suits their profile, is well paid, and allows them to work legally. ${ }^{107}$

Studies on migrant remittances, development, and return demonstrate that such population movements often result in "migration-dependent communities and the generation of further migration through the diffusion of consumerism." ${ }^{108}$ In this context, the "servants of globalisation" may also become "agents of globalisation," who introduce new consumption practices in their societies. ${ }^{109}$ In the case of female migrants from Western Ukraine who work in the care and cleaning sectors in Western Europe, Tolstokorova and Zimmer refer to the formation of "migration dynasties" where a new generation of migrants, raised by their grandparents, "repeat[s] the pattern of entrusting their own offspring to the next generation of grandparents." 110 Migratory experience, survival skills, integration strategies, and the wisdom of maintaining connected relationships and "virtual intimacies" from a distance are passed on from generation to generation. ${ }^{111}$ In the case of ethnic Ukrainian migration to Greece, further research is needed on this subject.

\section{Conclusion}

Ethnic Ukrainian migration to Greece can be characterised as global, transnational, and networked, principally economic, and largely female. The main push-factor has been economic, and the main pull-factors have been the existence of migration networks and the availability of work opportunities in the destination country. Discrepancies between the migration expectations and realities to a large extent have to do with expectations as far as working conditions, sociocultural integration, and the functioning of public institutions. In Greece, migrants have discovered a new life and 
new social values. They have made new acquaintances and have had to find solutions to new challenges. In the process, many migrants have learned to stand up for their rights and to respect themselves and others. As far as the "emancipatory project" of some female migrants is concerned, research suggests that work abroad only increases their double burden with "motherhood from afar," and perhaps as much as quadruples it if they have financial and care responsibilities in two locations. ${ }^{112}$ My interviewees, however, also underline that in Ukraine after the dissolution of the Soviet Union, they spent all their time working, first at work and then at home, additionally helping family members and relatives, whereas in Greece, they also have free time for themselves. So, was Greece an Eldorado for Ukrainian migrants? It was hardly so. Discrimination, difficult working conditions, social exclusion, and lack of consideration for their efforts in the host society, but also by their own family members who stayed in Ukraine, is the price they have paid for the material well-being of their families and a bit of personal freedom. In the case of older and middle-aged migrants with solid life and professional experiences, Ukraine has acquired added meaning as an exalted home and homeland. These migrants can be characterised as "long-distance nationals" and "heroes of the nation." ${ }^{113}$ In the case of migrants who have come to Greece at a young age, however, have acquired knowledge of the Greek language, integrated socioeconomically, and adapted culturally, Greece is important. It is the country of their present lives and where some of them see their future. In parallel, since the late 1990s, the emergence of a Ukrainian diaspora in Greece, ${ }^{114}$ with its cultural associations, schools, and religious institutions is actively taking place. ${ }^{115}$

\section{NOTES}

1. BALDWIN-EDWARDS Martin, "Mediterranean Migrations: Regionalism versus Globalisation," Finisterra - Revista Portuguesa de Geografia, vol. 39, n 77, 2004, p. 9-20.

2. tastsoglou Evangelia, Maratou-Alipranti Laura, "Gender and International Migration: Conceptual, Substantive and Methodological Issues," The Greek Review of Social Research, 2003 (Gender and International Migration: Focus on Greece), p. 5-22.

3. MASSEY Douglas et al., "Theories of International Migration: A Review and Appraisal," Population and Development Review, vol. 20, nº 3, 1993, p. 699-751.

4. VERTOVEC Steven, Transnationalism, London, Routledge, 2009.

5. PORTES Alejandro, The Economic Sociology of Immigration: Essays on Networks, Ethnicity and Entrepreneurship, New York, Russel Sage Foundation, 1995; CHRISTOU Anastasia, "Identities, Negotiating the Ethnos and Mapping Diasporas - Theoretical Challenges Regarding Empirical Contributions," Spaces of Identity, vol. 4, n 3, 2004, p. 53-70.

6. HELLERMANN Christiane "Migrating Alone: Tackling Social Capital? Women from Eastern Europe in Portugal," Ethnic and Racial Studies, vol. 29, n 6, 2006, p. 1135-1152.

7. PIORE Michael, Birds of Passage: Migrant Labour and Industrial Society, Cambridge, Cambridge University Press, 1979; fELLINI Ivana et al., "Recruitment Processes and Labour Mobility: The Construction Industry in Europe," Work, Employment and Society, vol. 21, nº 2, 2007, p. 277-298. 
8. RYAZANOVA-CLARKE Larisa, "Introduction: The Russian Language, Challenged by Globalisation," in Larisa Ryazanova-Clarke (ed.), The Russian Language outside the Nation, Edinburgh, Edinburgh University Press, 2014, p. 1-30 (11).

9. LEWITT Peggy, DE WIND Josh, VERTOVEC Steven, “International Perspectives on Transnational Migration: An Introduction," International Migration Review, vol. 3, n 37, 2003, p. 565-575.

10. BRETTELl Caroline, "Theorizing Migration in Anthropology," in Caroline Brettell, James Hollifield (eds), Migration Theory, London, Routledge, 2008, p. 113-159 (120).

11. TSUDA Takeyuki, "Global Inequities and Diasporic Return: Japanese American and Brazilian Encounters with the Ethnic Homeland," in Takeyuki Tsuda (ed.), Diasporic Homecomings: Ethnic Return Migration in Comparative Perspective, Stanford, Stanford University Press, 2009, p. 227-259 (227).

12. Ibid., p. 228-229.

13. Ibid., p. 255.

14. Ibid., p. 229.

15. VERMEULEN Hans, Culture and Inequality: Immigrant Cultures and Social Mobility in Long-Term Perspective, Amsterdam, Institute for Migration and Ethnic Studies, 2001; FUKUYAMA Francis, "Social Capital," in Lawrence Harrison, Samuel Huntington (eds), Culture Matters: How Values Shape Human Behaviour, New York, Basic Books, 2000.

16. B ARTH Fredrik, Ethnic Groups and Boundaries: The Social Organization of Culture and Difference, London, Allen and Unwin, 1969.

17. BRETTELL Caroline, "Theorizing Migration in Anthropology," op. cit.

18. GUPTA Akhil, fERGUSON James, "Beyond 'Culture': Space, Identity, and the Politics of Difference," Cultural Anthropology, vol. 7, nº 1, 1992, p. 6-23.

19. MICHAIL Domna, "Social Development and Transnational Households: Resilience and Motivation for Albanian Immigrants in Greece in the Era of Economic Crisis," Southeast European and Black Sea Studies, vol. 13, n 2, 2013, p. 265-279 (274).

20. Fieldwork for this article was carried out in the framework of the French School of Athens and its programmes, and thanks to the scholarships received from the Alexander Onassis Foundation $(2001,2010)$ and the Niilo Helander Foundation.

21. KAURINKosKi Kira, Les Grecs dans le Donbass. Analyse des identités collectives dans deux villages d'Ukraine orientale, Thèse de Doctorat, Université de Provence (Aix-Marseille I), 1997.

22. The first wave started in the late nineteenth century and lasted until World War I and consisted of the movement of rural populations in response to the political and economic oppression by the Russian and Austro-Hungarian imperial regimes. Ukrainians from Eastern Ukraine moved to Siberia and Altai, while those from Western Ukraine went to the Americas, in particular the USA, Canada, Argentina, and Brazil. The second wave occurred in the inter-war years and was shaped by similar movements. The third wave is composed of post-World War II migration and the socialist mobilisation projects of the 1950s and 1960s. The beginning of the fourth wave of migration, or labour migration, from Ukraine is attributed to the socio-economic changes that occurred in Ukrainian society after 1991, such as restructuring of the post-Soviet economy and labour markets, the significant rise in unemployment, long delays in payments of salaries, and currency and wage inflation. Contrary to the first three waves which have been characterised as political in nature, the fourth wave is socially and economically driven. FEDYUK Olena, KINDLER Marta, "Migration of Ukrainians to the European Union: Background and Key Issues," in Olena Fedyuk, Marta Kindler (eds), Ukrainian Migration to the European Union. Lessons from Migration Studies, IMISCOE Research Series, Springer Open, Centre of Migration Research, 2016, p. 1-14 (2-3).

23. HOFFMAN Martin, REICHEL David, Ukrainian Migration: An Analysis of Migration Movements to, through and from Ukraine, Vienna, ICMPD, 2011. 
24. A prolonged crisis in Ukraine began on 21 November 2013, when President Viktor Yanukovitch suspended preparations for the implementation of an association agreement with the European Union. This decision resulted in mass protests, known as "Euromaidan." On 22 February 2014, Yanukovitch was ousted from power by the protesters. Unrest in the largely Russophone Eastern and Southern regions of Ukraine followed. On 18 March Russia annexed Crimea after Crimeans voted to join the Russian Federation in a disputed referendum. In April 2014 unrest in the regions of Donetsk and Luhansk evolved into a war between the Ukrainian government and pro-Russian insurgents. By 2021, the unresolved conflict had produced more than 13,000 dead and 1.5 million displaced persons. Russia has denied its involvement, however, Ukraine, NATO, and the OSCE have reported the buildup of Russian troops and military equipment near Donetsk, and Russian and Ukrainian cross-border shelling.

25. MANSOOR ALI, QUILLIN BRYCE, Migration and Remittances. Eastern Europe and the Former Soviet Union, Washington D.C., World Bank, 2007.

26. KIRYAN Tetyana, VAN DER LINDEN Mariska N.J., Trafficking of Migrant Workers from Ukraine. Issues of Labour and Sexual Exploitation, Geneva, International Labour Organization (ILO), 2005; INTERNATIONAL ORGANIZATION FOR MIGRATION (IOM), Labour Migration Assessment for the Western Newly Independent States (WNIS), 2006; DÜVELL Franck, Ukraine - Europe's Mexico?, Research Resource Report 1, Oxford, COMPAS, 2006; MARKOV Ihor (ed.), НА РОЗДОРІЖЖІ. АНАЛІТИЧНІ МАТЕРІАЛИ КОМПЛЕКСНОГО ДОСЛІДЖЕННЯ ПРОЦЕСІВ УКРАЇНСЬКОЇ ТРУДОВОЇ МІГРАЦІЇ (КРАЇНИ ЄВРОПЕЙСЬКОГО СОЮЗУ І РОСІЙСЬКА ФЕДЕРАЦІЯ) [At the Crossroads: Analytical Materials of Complex Research about the Processes of Ukrainian Work Migration (Countries of European Union and Russian Federation)], Lviv, Papuha, 2009; тоцSтокоRova Alissa, "Bitter Berries of Better Life: SocioDemographic Costs of Labour Migration for the Ukrainian society," ENQUIRE online journal: https://www.nottingham.ac.uk/sociology/documents/enquire/vol-3-issue-1-tolstokorova.pdf (accessed in September 2021), vol. 3, $\mathrm{n}^{\circ} 1$ (Stories of Migration: Research, Theories and Everyday Lives), 2010, p. 58-80.

27. VOLODKO Viktoria, FEDYUK Olena, Annotated Bibliography of Ukrainian and Russian Language Sources on Ukrainian Labour Migration, Florence, Migration Policy Centre, European University Institute, 2012; МАRКОV (ed.), НА РОЗДОРІЖЖІ, op. cit.

28. FEDYUK, KINDLER, "Migration of Ukrainians to the European Union," op. cit.; NIKOLOVA Marina, Ukrainian Migration in Greece: There and Back Again and Straight Ahead for One more Time, Background Report: Migration System 2 (Ukraine), IRMA Project Concept Paper, Athens, ELIAMEP, 2013; NIKOLOVA Marina, "Ukrainian Migration to Greece: Patterns and Challenges of Remaining and Return," Central and Eastern European Migration Review, vol. 4, n 2, 2015, p. 107-120.

29. JAROSZEWITCZ Marta, "The Migration of Ukrainians in Times of Crisis," OSW Commentary, Centre for Eastern Studies, $n^{\circ}$ 187, October 2015, online: https://www.osw.waw.pl/sites/default/files/ commentary_187.pdf (accessed in September 2021).

30. DANZER Alexander, DIETZ Barbara, "Temporary Labour Migration and Welfare at the New European Fringe: A Comparison of Five Eastern European Countries," IZA Discussion Paper Series, $2009, \mathrm{n}^{\circ} 4142$.

31. DÜVELL Franck, "Quo vadis, Migration Studies?," Zeitschrift für Migrationsforschung, vol. 1, $\mathrm{n}^{\circ} 1$, 2021, p. 215-241 (228-229) ; VAN HEAR Nicholas, BRUBAKER Rebecca, BESSA Thais, "Managing Mobility for Human Development: The Growing Salience of Mixed Migration," UNDP Human Development Research Paper, 20, 2009 ; CRAWLEY Heaven, SKLEPARIS Dimitris, "Refugees, Migrants, Neither, Both: Categorical Fetishism and the Politics of Bounding in Europe's "Migration Crisis," Journal of Ethnic and Migration Studies, vol. 44, $\mathrm{n}^{\circ}$ 1, 2018, p. 48-64.

32. DÜVELL, "Quo vadis, Migration studies?", op. cit., p. 232; HIRSCHMAN Albert O., Exit, Voice and Loyalty: Responses to Decline in Firms, Organizations, and States, Cambridge, MA, Harvard University Press, 1970. 
33. LUTZ Helma, "Life in the Twilight Zone: Migration, Transnationality and Gender in the Private Household," Journal of Contemporary European Studies, vol. 12, 2004, p. 47-55 ; тоLSTOKOROVA Alissa, "Of Women's Bondage: Socio-Economic Effects of Labour Migration on the Situation of Ukrainian Women and Family," Acta Universitatis Sapientiae, Social Analysis, vol. 2, nº 1, 2012, p. 9-29 ; FEDYUK Olena, “The Gender Perspective in Ukrainian Migration," in Olena Fedyuk, Marta Kindler (eds), Ukrainian Migration to the European Union, op. cit., p. 73-89.

34. In 2001, women accounted for $72 \%$ of Ukrainians in Greece; their share has risen after the 2008 crisis. NIKOLOVA Marina, MAROUFOF Michaela, "Ukrainian Migration to Greece: From Irregular Work to Settlement, Family Reunification and Return," in Olena Fedyuk, Marta Kindler (eds), Ukrainian Migration to the European Union, op. cit., p. 151-162.

35. FEDYUK Olena, KINDLER Marta (eds), Ukrainian Migration to the European Union, op. cit.

36. GÓRNY Agata, KINDLER Marta, "The Temporary Nature of Ukrainian Migration: Definitions, Determinants and Consequences," in Olena Fedyuk, Marta Kindler (eds), Ukrainian Migration to the European Union, op. cit, p. 91-112.

37. PARSANOGLOU Dimitris, Grèce, pays d'immigration. Perspectives historiques et sociologiques, thèse de sociologie, Paris, EHESS, 2009.

38. PAPATAXIARCHIS Evthymios, "La Grèce face à l'altérité", Ethnologie française, vol. $35, \mathrm{n}^{\circ} 2,2005$, p. 203-212.

39. BALDWIN-EDWARDS Martin, Statistical Data on Immigrants in Greece: An Analytic Study of Available Data and Recommendations for Conformity with European Standards, Study Conducted for IMEPO (Migration Policy Institute), Greece, by MMO, UEHR, Athens, Panteion University, 2004.

40. BALDWIN-EDWARDS Martin, "Illegal Migration in the Mediterranean", $5^{\text {th }}$ International Seminar on Security and Defence in the Mediterranean, Barcelona, Barcelona Centre for International Affairs, 2007, p. 115-124.

41. KASIMIS Charalambos, “Greece: Illegal Immigration in the Midst of Crisis," Migration Information Source Online Journal, 2012, https://www.migrationpolicy.org/article/greece-illegal-immigrationmidst-crisis/ (accessed in May 2021); MICHAIL, "Social Development and Transnational Households," op. cit.; NIKOLOVA, MAROUFOF, "Ukrainian Migration to Greece," op. cit.

42. VELla Eugenia, "Emigration and Fiscal Austerity in the Greek Depression," ELIAMEP, Policy Brief, $\mathrm{n}^{\circ} 148,2021$, p. 3.

43. CHOLEZAS Ioannis, "Foreigners in the Greek Labour Market," Greek Economic Outlook, $\mathrm{n}^{\circ} 38,2019$, p. 39-45.

44. CHRISTOU Anastasia, MichAil Domna, "Migrating Motherhood and Gendering Exile: Eastern European Women Narrate Migrancy and Homing," Women's Studies International Forum, vol. 52, 2015, p. 71-81 (77).

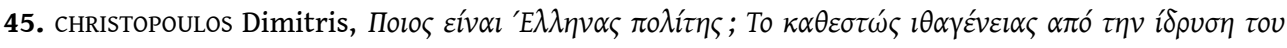

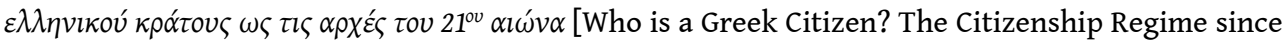
the Foundation of the Greek State to the Beginning of the $21^{\text {st }}$ Century], Athens, Vivliorama, 2012. 46. Communication by Angelos Syrigos, MP for New Democracy and Associate Professor at Panteion University, at a migration conference entitled "Reflections on the Current Situation," organised by the Citizens' Movement (Kinisi politon) at the Athens Music Hall, Athens, 28 January 2020.

47. FAWCETT James, "Networks, Linkages, and Migration Systems," International Migration Review, vol. 23, n 3, 1989, p. 671-680; NIKOLOVA, "Ukrainian Migration to Greece," op. cit.

48. BALDWIN-EDWARDS Martin, ARANJO Joaquin (eds), Immigrants and the Informal Economy in Southern Europe, London, Routledge, 1999; BALDWIN-EDWARDS Martin, "Semi-Reluctant Hosts: Southern Europe's Ambivalent Response to Immigration," The Brown Journal of World Affairs, 2002, p. 211-229. 
49. EMKE-POUloupoulos Ira, "Illegal Trafficking of Women and Girls for Sexual Exploitation: The

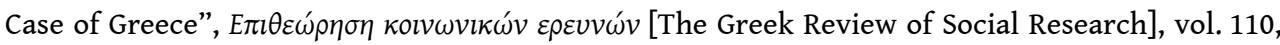
$\mathrm{n}^{\circ}$ A, 2003, p. 271-307; KIRYAN, VAN DER LINDEN, Trafficking of Migrant Workers from Ukraine, op. cit., p. 23 [updated following changes to initial reference].

50. NIKOLOVA, MAROUFOF, "Ukrainian Migration to Greece," op. cit., p. 160.

51. NIKolova, "Ukrainian Migration to Greece," op.cit; NIKOlova Marina, "The Dynamics of Ukrainian Migration to Greece: Routes, Decisions, Practices," IRMA Project Case Study, ELIAMEP, 2015.

52. Communication by Angelos Syrigos, op. cit.

53. KUKHARENKO R., "Ukrainians in Greece," in Migration - Migraciya, Kyiv, State Migration Service of Ukraine and the "Compassion" Foundation for Assistance to Refugees and Displaced People, 31.07.2017; МАRКОV (ed.), НА РОЗДОРІЖЖІ, ор. cit.

54. TSUDA, Diasporic Homecomings, op. cit.; VOUTIRA Eftihia, The "Right to Return" and the Meaning of "Home," Berlin, LIT Verlag, 2011.

55. Ethnic Greeks in Ukraine can be divided into three main subgroups: the Mariupol Greeks, the Pontic Greeks, and the descendants of Greek settlers from continental Greece and the Aegean and Ionian islands who arrived in South Russia in the eighteenth and nineteenth centuries. In addition, there was a small number of political refugees of the Greek Civil War (1946-1949). DMITRIENKO Maria et al. (eds), ГРЕКИ НА УКРАЇНСЬКИХ ТЕРЕНАХ. НАРИСИ З ЕТНІЧНОЇ ІСТОРЇ.. ДОКУМЕНТИ, МАТЕРІАЛИ, КАРТИ [Greeks on Ukrainian Lands. Images of an Ethnic History. Documents, Materials, Maps], Kyiv, Ukrainian Academy of Sciences, Lybid, 2000; KAURINKOSKI Kira, "Les Grecs de Mariupol (Ukraine). Réflexions sur une identité en diaspora," Revue européenne des migrations

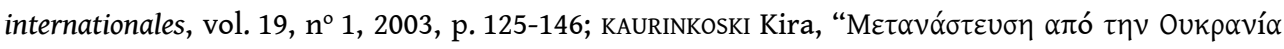

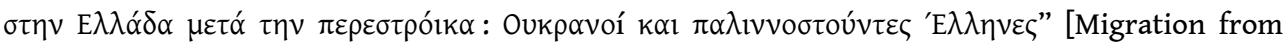
Ukraine to Greece since Perestroika: Ukrainians and Returning Ethnic Greeks], in Ekaterini

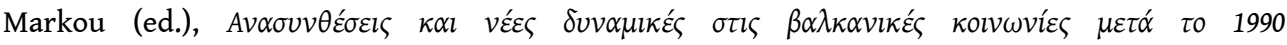
[Reconfigurations and New Dynamics in the Balkan Societies after 1990], Athens, Irodotos, 2011, p. 371-399; KAURINKOSKI Kira, Le "retour" des Grecs de Russie, Identités, mémoires, trajectoires, Athènes, Ecole française d'Athènes, 2018; KAURINKOSKI Kira, "Entre patrie et terre des ancêtres. Questions identitaires et mémorielles des Grecs de Mariupol en Ukraine et en Grèce," in Sophie ChaveDartoen, Stéphanie Rolland-Traina (eds), Le façonnement des ancêtres. Dimensions sociales, rituelles et politiques de l'ancestralité, Paris, Presses de l'Inalco, 2019, p. 259-289.

56. NIKOLOVA, MAROUFOF, “Ukrainian Migration to Greece”, op. cit., p. 153.

57. KOSMARSKAYA Natalya, “ЖЕНСКОЕ ИЗМЕРЕНИЕ” ВЫНУЖДЕННОЙ МИГРАЦИИ И МИГРАЦИОННОЕ ЗАКОНОДАТЕЛЬСТВО РОССИИ [“The Female Dimension" of Forced Migration and Migration Law in Russia], Moscow, Moscow Centre for Gender Studies, 1998.

58. Interview, Athens, 2005. See also KAURINKOSKI Kira, "Gendered Migration Patterns and Experiences of Ukrainian Immigrants in Greece," in Alexandra Ioannidou, Christian Voss (eds), Spotlights on Russian and Balkan Slavic Cultural History, Studies on Language and Culture in Central and Eastern Europe, Munich, Kubon und Sagner, 2009, p. 39-55.

59. тоLSтокоRоva Alissa, "Economic Inequality, Social Exclusion and Labour Migration: Challenges to Ukrainian Youth Over Post-Soviet Transition," Forum 21: European Journal on Youth Policy, 2007, vol. 10-12, p. 97-107 (103); ROVENCHAK Olga, vOLODKO Viktoria, УКРӒ̈НСЬКІ ТРУДОВІ МІГРАНТИ В ГРЕЦІї (ГЕНДЕРНИЙ АСПЕКТ) [Ukrainian Labour Migrants in Greece (Gender Aspect)], West Analytic Group, 2010, online: https://clio.lnu.edu.ua/wp-content/uploads/2015/11/26.pdf (accessed in September 2021).

60. CASTLES Steven, MILLER Mark, The Age of Migration, Houndmills-Basingstoke-Hampshire, Palgrave MacMillan, 2003. 
61. KAURINKOSKI, "Les Grecs de Mariupol (Ukraine)," op.cit;; KING Russell, LAZARIDIs Gabriella, TSARDANIDIS Charalmbos (eds), Eldorado or Fortress? Migration in Southern Europe, London, Palgrave Macmillan, 2000.

62. KAURINKOSKI, "Gendered Migration Patterns and Experiences of Ukrainian Immigrants in Greece," op. cit.; KAURINKOSKI, Le "retour" des Grecs de Russie, op. cit.

63. FAKIOLAS Rossetos, MARATOU-ALIPRANTI Laura, "Foreign Female Immigrants in Greece," Papers: Revista de Sociologia, vol.60, 2000, p.101-117; KAURINKOSKI, "Gendered Migration Patterns and Experiences of Ukrainian Immigrants in Greece," op. cit.

64. тоLsтокоRova Alissa, "Mary Poppins Comes Back: The Revival of Paid Domestic Work in the Informal Labour Market in Ukraine," Südoseuropa, vol.62, n 4, 2014, p. 479-499 (484); TRIMIKLINIOTIS Nikos, fULIAS-SOURoulla Mihaela, "Informalization and Flexibilization at Work: The Migrant Women Precariat Speak," in Floya Anthias, Maria Kontos, Mirjana Morokvasic-Müller (eds), Paradoxes of Integration: Female Migrants in Europe, London, Springer, 2013, p. 59-78.

65. According to 2001 census data, $66 \%$ of women from Ukraine in Greece worked in "other" sectors, a category which includes domestic labour. Approximately $20 \%$ worked in the tourism sector and approximately $10 \%$ in the agricultural and industrial sectors. Among Ukrainian men in Greece, $80 \%$ worked as craftsmen, drivers, unqualified workers, or in small businesses, $5 \%$ worked in the service sector or as sales personnel in shops or open-air markets, $5 \%$ worked in the agriculture sector, $5 \%$ declared their profession unclearly or did not declare profession, the remaining were scientists, artists, technicians, or managers. BALDWIN-EDWARDS, Statistical Data on Immigrants in Greece, op. cit.

66. KAURINKOSKI, "Gendered Migration Patterns and Experiences of Ukrainian Immigrants in Greece," op. cit.

67. Interview, Athens, 2005. See also, KAURINKOSKI, Le "retour" des Grecs de Russie, op. cit.

68. According to the 2011 census, Ukrainians were employed mainly in domestic work and hotel and catering services, followed by retail, motor repairs, administrative and support service activities, manufacturing, and construction. NIKOLOVA, MAROUFOF, "Ukrainian migration to Greece," op. cit., p. 155-157.

69. TASTSOGLOU Evangelia, HADJICOSTANDI Joanna, "Never outside the Labour Market, but always Outsiders: Female Migrant Workers in Greece," Gender and International Migration, op.cit., p. 189-220; KAURINKOSKI, “Gendered Migration Patterns and Experiences of Ukrainian Immigrants in Greece," op. cit.

70. Interview, Athens, 2005. See also, KAURINKOSKI, “Gendered Migration Patterns and Experiences of Ukrainian Immigrants in Greece," op. cit.

71. Ibid.; TOLSTOKOROVA, "Of Women's Bondage," op. cit.

72. In Greece, the possibility of family reunification was introduced by Presidential Decree $131 / 2006$.

73. KAURINKOSKI, "Gendered Migration Patterns and Experiences of Ukrainian Immigrants in Greece," op. cit.; KAURINKOSKI, Le "retour" des Grecs de Russie, op. cit.

74. LAZARIDIS Gabriella, POYAGO-тНЕотокY Joanna, "Undocumented Migrants in Greece: Issues of Regularization," International Migration, vol. 37, $\mathrm{n}^{\circ} 4$, p. 715-740; SINTES Pierre, La raison du mouvement. Territoires et réseaux de migrants albanais en Grèce, Paris-Athènes, Karthala, MMSH, Ecole française d'Athènes, 2010.

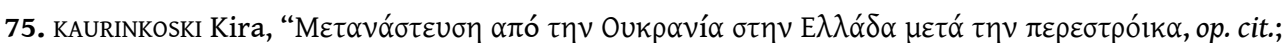
KAURINKOSKI, "Gendered Migration Patterns and Experiences of Ukrainian Immigrants in Greece," op. cit.

76. ROVENCHAK Olga, СОЦІОЛОГІЧНА КОНЦЕПТУАЛІЗАЦІЯ СУЧАСНОÏ МІЖНАРОДНОЇ МІГРАЦІї ЯК СОЦІОКУЛЬТУРНОГО ФЕНОМЕНУ ЕПОХИ ГЛОБАЛІЗАЦІї [A Sociological Conceptualisation of Modern 
International Migration as a Socio-Cultural Phenomenon in a Globalising World], PhD Thesis, Kharkiv, National V. N. Karazin University of Kharkiv, 2011.

77. In December 2011, 16,570 Ukrainians in Greece held a valid residence permit: 7,736 were issued for employment and 5,500 for marriage with EU citizens, mainly Greeks. NIKOLOVA, MAROUFOF, "Ukrainian Migration to Greece," op. cit.

78. KAURINKOSKI, Le "retour" des Grecs de Russie, op. cit.

79. Oral communication, President of the Association of the Ukrainian Diaspora in Greece "Ukrainsko-Grecka Dumka", Athens, June 2015 and earlier dates.

80. KAURINKOSKI, Le "retour" des Grecs de Russie, op. cit.

81. тоLSTokorova Alissa, “'Servants of Globalization' or New Middle-Class Elite? Impact of International Labour Migration on Socio-Economic Status of Ukrainian Women," Materials of the $31^{\text {st }}$ General Conference of the International Association for Research in Income and Wealth, St Gallen, Switzerland, 22-28 August 2010; тоLSTOKOROVA, "Bitter Berries of Better Life," op. cit.

82. тоLSTOKOROVA, "Of Women's Bondage," op. cit.; NIKOLOVA, "Ukrainian Migration to Greece," op. cit.

83. Interview, Athens, 2005. See also, KAURINKOSKI, Le "retour" des Grecs de Russie, op. cit.

84. PARREÑAS Rhacel, Servants of Globalisation: Women, Migration, and Domestic Work, Stanford, Stanford University Press, 2001.

85. Ibid.

86. KUKHARENKO, "Ukrainians in Greece", op. cit.

87. The ancient Slavs believed in Beregynia - the Great Goddess that produced all things. Since the Ukrainian independence in 1991, Beregynia (Ukr. Berehynia) has undergone a folkloric metamorphosis and is today identified as a combination of the "hearth-mother" (associated with the guardianship of the nation) and a rusalka (mermaid). This metamorphosis has its roots in the late 1980s, as several Ukrainian writers sought to personify their vision of an ideal Ukrainian woman. Beregynia is thus perceived as a protector of the nation, the family, and a protector of women. However, many scholars argue that Beregynia is a spirit and not a Goddess. In 2001, a column with a sculpture of Beregynia on top was erected at Independence Square in central Kyiv, on the site of the former Lenin monument. The monument is to serve as a protector of the city, with an older monument located just across the square - that of the city's historic protector Archangel Michael. NIKLOT, "Bereginya - The Slavic Spirit of Protection", Slavicchronicles.com, June 2017, online: http://slavicchronicles.com/mythology/bereginya-the-slavic-spirit-of-protection/ (accessed in September 2021).

88. MARKOV (ed.), НА РОЗДОРІЖЖІ, ор. cit., p. 226.

89. The Ukrainian Greek Catholic Church is a Byzantine Rite Eastern Catholic church in full communion with the Pope and the worldwide Catholic Church. It appeared in 1596, with the signing of the Union of Brest between the Ruthenian Orthodox Church and the Holy See. Following the partitions of Poland, in 1808 the eparchies of the original Ruthenian Uniate Church were split between the Austrian Empire, Prussia, and the Russian Empire. In 1963, the church was recognised as Ukrainian. Within Ukraine, the Ukrainian Greek Catholic Church ranks third in allegiance after the Ukrainian Orthodox Church (Moscow Patriarchate) and the Orthodox Church of Ukraine. The Ukrainian Greek Catholic Church predominates in three western oblasts (regions) of Ukraine, including the city of Lviv, but constitutes a small minority elsewhere in the country. The church has followed the spread of the Ukrainian diaspora and has some forty hierarchs on four continents. The Church in the diaspora is largely multi-ethnic.

90. ROVENCHAK, VOLODKO, УКРАЇНСЬКI ТРУДОВI МІГРАНТИ В ГРЕЦЇ (ГЕНДЕРНИЙ АСПЕКТ), op. cit.

91. MARKOV (ed.), НА РОЗДОРІЖЖІ, op. cit.

92. KAURINKOSKI Kira, "Constructing Home away from Home: The Case of the Interwar Russian Refugees and the Post-Soviet Migrants in Greece," in Maria Yelenevskaya, Ekaterina Protasova 
(eds), Material Culture of the Russian-Speaking Diaspora: The Social Semiotics of Home, Edinburgh, Edinburgh University Press (forthcoming).

93. KAURINKOSKI, Le "retour" des Grecs de Russie, op. cit.

94. тоLSTоKoRova, “'Servants of globalization' or new middle-class elite?," op.cit.; NIKolovA, "Ukrainian Migration to Greece," op.cit.; FEDYUK, KINDLER, "Migration of Ukrainians to the European Union," op. cit.

95. LEONTIYeVA Yana, "Ukrainian Migration to Europe: Policies, Practices and Perspectives," Central and Eastern European Migration Review, vol. 3, n ${ }^{\circ}$ 1, 2014, p. 5-10; FEDYUK, KINDLER, Ukrainian Migration to the European Union, op. cit.

96. DAYTON-JOHNSON Jeff et al., Gaining from Migration. Towards a New Mobility System, Paris, OECD, 2007.

97. ROVENCHAK, VOLODKO, УКРАЇНСЬКI ТРУДОВI МІГРАНТИ В ГРЕЦЇ̈ (ГЕНДЕРНИЙ АСПЕКТ), op. cit.

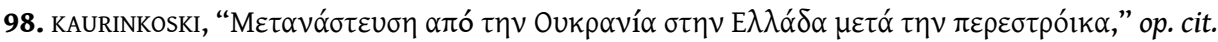

99. LeVChenKo Kateryna, Ukrainian Greece: Reasons, Problems, Prospects (According to Labour Migrants' Interviews), Kyiv, Agency "Ukraine”, 2010; NIKOLOVA, MAROUFOF, "Ukrainian Migration to Greece," op. cit., p. 158.

100. NIKOLOVA, MAROUFOF, "Ukrainian Migration to Greece," op. cit.

101. MICHAIL, "Social Development and Transnational Households," op. cit.

102. FITZGERALD David, "Immigrant Impacts in Mexico: A Tale of Dissimilation," in Susan Eckstein, Adil Najam (eds), How Immigrants Impact their Homelands, Durham, Duke University Press, 2013, p. 114-137; FITZGERALD David, "The Sociology of International Migration," in Caroline Brettell, James Hollifield (eds), Migration Theory: Talking across Disciplines, New York, Routledge, 2014, p. 115-147; KAURINKOSKI, Le "retour" des Grecs de Russie, op. cit.

103. LEWITT Peggy, The Transnational Villagers, Berkeley, University of California Press, 2001.

104. CHRISTOU Anastasia, "Deciphering Diaspora - Translating Transnationalism: Family Dynamics, Identity Constructions and the Legacy of 'Home' in Second Generation GreekAmerican Return Migration," Ethnic and Racial Studies, vol. 29, nº 6, 2006, p. 1040-1056; KING Russell, CHRISTOU Anastasia, AHRENS Jill, “'Diverse mobilities': Second-Generation Greek-Germans Engage with the Homeland as Children and as Adults," Mobilities, vol. 6, $\mathrm{n}^{\circ}$ 4, 2011, p. 483-501.

105. NIKOLOVA, "Ukrainian Migration to Greece," op. cit.

106. KAURINKOSKI, Le "retour" des Grecs de Russie, op. cit.

107. NIKolovA, "Ukrainian Migration in Greece," op. cit.

108. BRETTELL, “Theorizing Migration in Anthropology," op. cit., p. 119.

109. SERAIDARI Katerina, "L'internationalisation du gout: activités marchandes des immigrés grecs en Belgique et en Australie," Emulations, vol. 26, 2018, p. 105-116.

110. TOLSTOKOROVA, "Of Women's Bondage," op. cit., p. 14-15; ZIMMER Kerstin, "How Labour Migration is Changing Ukraine," Business Week, $\mathrm{n}^{\circ} 22,2007$.

111. WILDING Raelene, “'Virtual' Intimacies? Families Communicating across Transnational Contexts," Global Networks, vol. 6, 2006, p. 125-142; тоцSтокоRоva, "Of Women's Bondage," op. cit., p. 15.

112. TOLSTOKOROVA, "Of Women's Bondage," op. cit.; SANCHEZ-CARRETERO Cristina, "Motherhood from Afar: Channels of Communication among Dominican Women in Madrid," A European Journal of International Migration, vol. 43-45, 2005, p. 145-163.

113. SOLARI Cinzia, "Theorizing the Ukrainian Case: Pushing the Boundaries of Migration Studies through a Europe-US Comparison," in Olena Fedyuk, Marta Kindler (eds), Ukrainian Migration to the European Union, op. cit., p. 215-227.

114. On definitions of diaspora, e.g., Robin COHEN, Global Diasporas: An Introduction, London-New York, Routledge, Second edition, 2008 (1997). In this book, Cohen explores the changing meaning 
of the concept and the contemporary diasporic condition. A chapter is dedicated to labour diaspora.

115. KAURINKOSKI, “Constructing Home away from Home," op. cit.

\section{ABSTRACTS}

This paper discusses transnational labour migration from Ukraine to Greece since the end of the Cold War. It examines the migration context, motivations, and expectations. It then discusses the actual experiences of Ukrainian migrants, in Greek society and beyond, and their visions for the future. The paper touches upon the 2008 crisis in Greece and its impact on migrants and their choices. The paper also discusses the social organisation of Ukrainian migrants in Greece, as well as identity and belonging, in a globalised world. Whereas many Ukrainian migrants continue to perceive their stay in Greece as temporary, the emergence of a Ukrainian diaspora community in Greece is imminent. The paper is based on primary research conducted by the author in greater Athens, as well as secondary sources.

Cet article traite de la migration transnationale de la main-d'œuvre de l'Ukraine vers la Grèce depuis la fin de la guerre froide. Il examine le contexte du départ, ainsi que les motivations et les attentes des migrants. Il discute ensuite les expériences vécues des migrants, dans la société grecque et au-delà, ainsi que leurs visions de l'avenir. L'article aborde également la crise de 2008 et son impact sur les choix des migrants. L'organisation sociale des migrants ukrainiens en Grèce et les questions identitaires et d'appartenance font également l'objet d'une analyse. Bien que nombre de migrants ukrainiens continuent à percevoir leur séjour en Grèce comme temporaire, l'émergence d'une communauté diasporique ukrainienne en Grèce semble imminente. L'article se fonde sur des enquêtes de terrain menées par l'auteur dans la grande Athènes, ainsi que sur des sources secondaires.

\section{INDEX}

Mots-clés: diaspora ukrainienne, migration transnationale, migration de travail, identités, Europe du Sud

Keywords: Ukrainian diaspora, transnational migration, labour migration, identities, Southern Europe

\section{AUTHOR}

\section{KIRA KAURINKOSKI}

Aix-Marseille University, Institut d'ethnologie méditerranéenne européenne et comparative (UMR 7307), Aix-en-Provence, France

kaurinkoski[at]yahoo.fr 